\title{
Robert Young and the ironic authority of postcolonial criticism
}

\begin{abstract}
When I chanced on postcolonial scholar Robert Young's Textual Practice review of Gayatri Chakravorty Spivak's Outside in the Teaching Machine, I was startled to find an attack on Benita Parry among its pages. ${ }^{1}$ It comes early on, when Young is preparing the ground for a detailed exposition of Spivak's book by comparing Spivak's general critical standing with that of Edward Said and Homi Bhabha (who together create Young's chief constellation of postcolonial theorists). This then is the attack itself, in context:
\end{abstract}

Spivak differs from Said and Bhabha, however, in so far as she has not been so widely attacked for alleged obscurity, ungrounded theoreticism, or questionable political agendas. The stance of moral reproof that is customarily wielded against Bhabha or Said is already Spivak's own. And when she is attacked, her responses are sharply to the point: 'When Benita Parry takes us to task for not being able to listen to the natives, or to let the natives speak, she forgets that the three of us, postcolonials, are "native" too'. Spivak's rejoinder points to the political irony of three Black writers being attacked by an émigré South African critic during the era of apartheid. Her comment prompts the reader to ask what political agenda, what political priorities, drive such offensives. (pp. 229-30; emphasis added)

Why is it there?

It is interesting that Spivak's defensiveness here should have recourse to the very 'ethnic identitarianism' to which she elsewhere is frequently opposed. Young's preceding paragraph itself bears witness to that opposition:

It is typical of Spivak that she should spell out the history of the perspective from which she writes: most 'postcolonial' academics are economic migrants, either permanent or habitual, but some play this 
down in an effort to be taken as authentic spokespersons for 'the third world'. Spivak disdains this small-time institutional game, and is always disarmingly up-front about her own provenance. The effect of this in her work is that she pays attention to texts of the 'third world' not as representative writings of the other with whose voice she seeks to be identified, but in terms of the problematics of how they are read in the Western academic institution. (p. 229; emphasis added)

Spivak's self-representation as a 'postcolonial native', in response to Parry, is perhaps an example of the 'strategic essentialism' which is part of her theoretical arsenal. Parry's critique does not, in fact, charge 'the three' black writers (Spivak, Bhabha, JanMohamed) with silencing 'the natives'; it is only Spivak's work which is thus represented. Spivak's generalisation of a racial 'we' rests on a misreading, then, one that does not respect the nuances of Parry's argument and analysis. Quite possibly both Parry and Spivak have misread one another. ${ }^{2}$ Such misreadings have been productive, to judge by the animated debates which still attach to the question of subalternity.

In any case, my concern here is not with elucidating Spivak's own complex discourses, nor with adding to the debate on subalternity. What concerns me rather is Robert Young's intercession against Parry, the assumptions about power and intellectual authority written into his language use, and the implications of these for postcolonial critical dialogue and analysis. I will pass over the temptation to milk the Youngian 'irony' that it was this same Robert Young who as editor of the Oxford Literary Review in 1987 was responsible for the publication of Parry's 'offensive' in the first place. ${ }^{3}$ But I will later return to the notion of 'irony', for in Young's use of the word lies a lot of what is problematic about his discursive authority.

Recent metropolitan postcolonial criticism has - thanks in part to Spivak's own work - increasingly moved to a materialist awareness of, and concern with, (institutional, regional, professional, socio-economic) 'locations' in which postcoloniality is produced and circulated. Robert Young's intervention here instead emphasises ethnic or national 'origins' of critics in isolation from, and at the expense of, such 'locations'. Crucial to note here is the inconsistency, the doubleness of Young's standards: he deems ethnicity to be most significant in Spivak's case, but when it comes to Parry switches tack to emphasise the category of nationality. (I wonder what might have resulted had he brought Parry's Jewishness 
into the discussion!) That he feels able unselfconsciously and arbitrarily to differentiate and play off his subjects in this way, is, I think, symptomatic of the unquestioned assumptions of authority and power which animate his discourse here.

I question the intellectual validity and the political utility of deducing an individual's politics from the mere fact of their birthplace. That Benita Parry's writing does not do the business of the apartheid state but rather pursues a recognisably socialist-national liberationist perspective is clear to this reader, and I encourage other readers to judge for themselves rather than take Robert Young's textual prejudgements seriously. Since, however, Young chooses to privilege the experiential rather than the textual sphere in assessing the politics of Parry's work, I feel coerced into countering his judgement through enlisting my own personal experience of Parry's extratextual activities. Anyone who knows Benita Parry personally knows that this 'émigré, like many fellow South African socialist Jews, played a militant active role in the liberation movement before leaving - at a time when many activists both black and white were leaving for urgent political reasons - to continue her political activism in a far left movement in England.

Of two possibilities, I don't know which I find more troubling. One is that Robert Young made his insinuations in ignorance of Parry's political history, in ignorance of South Africa's political history - which ignorance itself would suggest a certain contemptuous disrespect of the country as undeserving of research. The other is that he did know of Parry's involvement in anti-government opposition, but considered this irrelevant to the discussion of her political 'agenda' and 'priorities'. The latter prospect makes me worry about the definitions of politics, of race, and of the psyche, being deployed by Young.

On South Africa: I venture to say that not only that country but Western knowledge-production of it stand at a critical juncture right now. New material opportunities have emerged for increased British, European and North American academic intellectual exchange, and enquiry. More striking, perhaps, than the increase in research fellowships is the rise in shortterm visits; South Africa is enjoying a veritable flood of US and UK dignitaries on lecture tours and conference platforms. Spivak herself, Fredric Jameson, Terry Eagleton, Ania Loomba, Dipesh Chakrabarty, Jonathan Dollimore and Alan Sinfield are among the radical critics to have recently visited the country on such terms. None the less, because 'South Africa' has acquired, in the West, the fetishistic status of racial allegory, the danger is that Western-located academics assume, to use a phrase of 
Spivak's, a relation of 'sanctioned ignorance' of that country. The kind of presumption evident in Young's commentary - that South Africa is immediately knowable, its non-black intellectuals automatically reducible to politically repressive agendas - itself licenses metropolitan 'neo-colonialist' dynamics of knowledge-production, in which South African intellectuals themselves are considered unworthy of critical engagement.

One has only to contrast Robert Young's summary dismissal of Parry's work and politics with his serious description of, and respectful engagement with, the Marxist anti-postcolonial work of Indian critic Aijaz Ahmad in this same review, to observe the ways in which South Africa and its products may somehow license metropolitan critics to depart from their general intellectual standards of assessment, from their rigorously academic modes of operation. 4

To return to the matter of Young's unstable discursive modalities: interestingly, his abstract (ethnic/national) determinism here is sometimes accompanied by a more materialist mode, conveyed in his occasional references to geographical and historical specificity. Far from mitigating the effects of determinism, such materialism is deployed to compound it. Benita Parry's 'politics' are undermined not only through pointing to her South African roots but also by attaching to her the label of 'émigré', with its associations of high-class privilege and political reactionariness. She comes under suspicion for being born there and for having left.

A situational concern also seems implicit in Young's castigation that Parry's critique was written and published 'during the era of apartheid'. Had Parry's piece been published in a South African journal in violation of the ANC academic boycott - had it, in other words, actually contributed to the apartheid regime - then Young's pronouncement might have more than cheaply gestural import. In any case, no sooner does he evoke this historically specific 'era', and with it an intersubjective emphasis on the social contexts, effects and sources of political meaning, than he shifts to an attack on 'the political priorities driving' Parry. As his use of the word 'drives' reveals, what is of ultimate import to Young in judging, in defining, the 'political' value of a piece of writing is its author's psyche alone. If so much hangs on the psychic matrix, then it is surprising that so little theorisation attends it. As with South Africa the country, so with the psyche: fully knowable spaces (to name is to know), involving the critic in no mediatory labour.

All this amounts to variations on a theme of unacknowledged powergames. If Young's assumptions authorise him to determine a critic's 
politics from her birthplace, to divine their psyche likewise, they also authorise him to determine for whom ethnicity is the key category and for whom nationality. They allow him to harness materialist terms to idealist and nominalist ends. They allow him to allege political 'irony' of a South African immigrant engaging in critical dialogue with an Indian immigrant. Young's language of 'irony' here seems to rely on, and hence produce, a hierarchy of critical mentalities. If you don't get the irony, it's because you are either not sufficiently sophisticated as a literary critic or you are yourself mired too deep in something nasty that might begin with ' $r$ '. What we are witnessing is a kind of literary elitism passing itself off as 'PC'; and the introduction of fundamentally literary categories as the exclusive basis for analysis of ethnic and political social issues. This to me is an anti-democratic practice that allots the postcolonial franchise to a selected few, removing it from others on the grounds of their ethnic origin.

Most questionable of all, for me, is the way Young opts to remain invisible while graphically scrutinising others. Young's insistent emphases on nationality and ethnicity as determinants in the political identity of Parry and Spivak have no corollary in a national or ethnic self-description. Quick though he is to interrogate Parry there is not a trace of self-questioning. Shades, perhaps, of imperial discourse. ${ }^{5}$

\section{Postscript/supplement}

It's not only South Africa as a country, nor South African-born academics that are subject to 'political' postcolonial censure. I too have experienced this, and for the same immediate reasons as Parry, namely, offering a critique of Gayatri Spivak's work for the ways it structurally excludes voices from certain parts of the world from being heard. Several years ago I published an article in Critical Quarterly, in which I argued that Spivak's reading of Jane Eyre, particularly her contention that the Caribbean Bertha Mason's death-by-fire required to be read in the context of colonial contests over Indian practices of sati, reflected an Indiacentrism found elsewhere in her work. ${ }^{6}$ I questioned the political effect of granting colonial epistemological primacy to India so that the meanings of such explicitly African and Caribbean figures such as Baudelaire's mistress and Bertha Mason were seen only to derive from Indian matrices. I found this problematic in that it appeared to deny those figures and colonies their own epistemological significance to a 
European imperial subject-formation and political project. My concern stemmed from a materialist and Africanist discomfort with the hegemony of Asian models in colonial discourse analysis, its possible effect on the future theorisation of non-Asian materials.

Critical Quarterly subsequently carried a negative description of my piece as the work of a neo-colonialist; in criticising her I performed a gesture analogous to 'the coloniser's displacement of the colonised'.7 Spivak, my critic suggested, was a 'representative colonised voice'. In his haste to impute a neo-colonialist subject-position to me, Pimomo did not stop to question the large problems attached to conferring colonised 'representativeness', nor did it occur to him, when basing his critique on (among other things) ethnic-identitarian premises, that I too might also have 'colonised' allegiances and concerns. My own experience as the black multiracial daughter of a black Marxist academic, the publisher and editor of the US journal The Black Scholar, has been crucial in making sense of my own responses to postcolonial debates. But at the same time, arguments in postcolonial studies surely cannot stand or fall on the basis of each critic's national/racial origins. And any critic who elevates Spivak as an exclusive or foundational example of black colonised subjectivity, and proceeds to measure other critics' politics (and ethnicity) according to whether they share this conviction, is likely to produce a compromisingly authoritarian critical practice.

\section{Notes}

Many thanks to Denise deCaires Narain, David Johnson, Neil Lazarus and Vicky Lebeau for helpful discussions and critical feedback.

1 Robert J. C. Young, Textual Practice, 10, 1 (1996), pp. 228-38.

2 Spivak has offered a retrospective and clarificatory account of her subaltern argument, which explains that she did not aim to silence 'the natives'. See Donna Landry and Gerald MacLean (eds.), The Spivak Reader (London: Routledge, 1996), pp. 287-90. See also Meyda Yegenoglu and Mahmut Mutman, 'Mapping the Present: Interview with Gayatri Spivak', New Formations: A Journal of Culture/Theory/Politics, 45 (2001), pp. 9-23, for Spivak's account of how the practice and conceptualisation of subalternity has changed since she wrote and published her original essay. Neil Lazarus provides an insightful contribution to the Spivak/Parry debate: 'Nationalist Consciousness and the Specificity of (Post)colonial Intellectualism', in Francis Barker, Peter Hulme and Margaret Iversen (eds.), Colonial Discourse/Postcolonial Theory (Manchester: Manchester University Press, 1994), pp. 197-220. 
3 Benita Parry, 'Problems in Current Theories of Colonial Discourse', Oxford Literary Review, 9, 1-2 (1987), pp. 27-58.

4 Robert Young's recent Postcolonialism: An Historical Introduction (Oxford: Blackwell, 2001) maintains problematic assumptions about South Africa. This passage, from the section on 'South Africa' in the chapter titled 'Africa 1: Anglophone African Socialism', articulates a number: 'Of all groups with Trotskyist links, the Unity Movement was the most significant ... Despite its name, it became increasingly opposed to the alliance between the S.A.C.P. [South African Communist Party] and the A.N.C., without ever being able to compete with the material as well as political support that the former was able to offer. Subsequent alternative Left forms of political opposition, such as Biko's Black Consciousness movement, were all too effectively repressed by the apartheid regime. In the end it was the S.A.C.P. and above all the A.N.C., which, with global international assistance in the form of economic and cultural sanctions, succeeded. It is striking that though Mandela refused to renounce the armed struggle, his political strategies remained close to those of Gandhi's almost a century earlier' (p. 232; emphasis added).

Young's hierarchical and 'great man' discourse leads to the ranking of political movements in terms of 'significance' and 'success'; it characterises Black Consciousness in terms of a single individual. Young's gratuitous nominalism generates a judgemental 'irony' in the fact that the Unity Movement, 'despite its name', opposed the alliance of the SACP and the ANC. And his Textual Practice respect for India over South Africa is also evident here, in the construction of the arms-advocate Mandela as a belated exemplar of Gandhian non-violence.

5 For other critical discussions of Robert Young's contributions to postcolonial critique see Aijaz Ahmad, 'The Politics of Literary Postcoloniality', Race and Class, 36, 3 (1995), pp. 1-20; Stuart Hall, 'When Was the "Post-colonial"? Thinking at the Limit', in Iain Chambers and Lidia Curti (eds.), The Post-colonial Question: Common Skies, Divided Histories (London: Routledge, 1996), pp. 242-60; David Johnson, 'Importing Metropolitan Post-colonials', Current Writing: Text and Reception in Southern Africa [Durban, South Africa], 6, 1 (1994), pp. 73-85; Bill Schwarz, 'Conquerors of Truth: Reflections on Postcolonial Theory', in Bill Schwarz (ed.), The Expansion of England: Race, Ethnicity and Cultural History (London: Routledge, 1996), pp. 9-31.

6 Laura Chrisman, 'The Imperial Unconscious? Representations of Imperial Discourse', Critical Quarterly, 32, 3 (1990), pp. 38-58. A similar point about Indian hegemony has been made by Arif Dirlik in 'The Postcolonial Aura: Third World Criticism in the Age of Global Capitalism', Critical Inquiry, 20 (1994), pp. 328-56.

7 Paulus Pimomo, 'The Centre Writes/Strikes Back?', Critical Quarterly, 33, 3 (1991), pp. 43-7. 